\title{
A Contrasting Evaluation of Consumer Purchase Attitude-behavior of Urban-Rural Working Women Consumers towards White-Brown Durables, a Study with Specific Relevance to Kochi, Kerala
}

Anilkumar $\mathrm{N}^{1 *}$ and Jelsy Joseph ${ }^{2}$

${ }^{1}$ Research Scholar and Chief Manager, Department of Commerce and Business Management, Karpagam University, Coimbatore, India ${ }^{2}$ Former Dean, Department of Commerce and Business Management, Karpagam University, Coimbatore, India

\begin{abstract}
Consumer centric marketing style is predominant in the durables, which in turn revolves around the consumer purchase attitude. It is known that Consumer attitude is a learnt predisposition to respond to an object or act consistently in a favorable or unfavorable manner and is shaped by one's values and beliefs which are learnt. Only by changing the consumer's attitude can they be influenced to enact a merchandise transaction in the marketing milieu. Hence the importance of attitude change is of paramount importance to marketers who are consumer focused in the modern age often customizing the products/services to match the tastes of the consumer by proper positioning and targeting strategies. Consumer segments may be urban or rural based on the peculiarities /residential location and outlook /lifestyle characteristics of the consumer. In this paper, an evaluation of the Urban and Rural Consumer Purchase attitude-Behavior, a Comparative Study of various facets with Special Reference to Consumer Durables (both white and brown goods) with the sample frame of middleclass working women families of Ernakulam (Kochi), the premier test marketing site in Kerala, is attempted herein. Based on the rich findings, the future strategies in market segmentation and market mix can be redesigned to match with current consumer tastes.
\end{abstract}

Keywords: Consumer attitude; Attitude change; Consumer behavior; Attributes; Consumer durables; White goods; Brown goods; FLCS; Family size; Market segmentation; Product positioning; Decision rules in purchase; Working women consumers; Rural/Urban consumption; Middle class (MC)

\section{Introduction}

We are aware that the Indian rural market consists of nearly 625 million consumers, almost $74 \%$ of the total market share for consumer goods. The rural consumer profile may be different from that of their urban counterparts in terms of education, income, occupation, reference group and media habits. While the average penetration levels for consumer durables in India is quite low, it is more so in the rural areas. There exist huge latent market waiting to be tapped in rural India with the right product-price combination. There is a shifting consumer preference for durables for the past decade with the influx of modern technology. The consumer buying preferences are rapidly changing and moving towards high-end latest technology products with acculturation. Driving the consumers towards products which were once considered luxury items but now a necessity is the changing lifestyle fueled by rising income levels. With increasing disposable incomes, the demand for high-end products such as ACs, Plasma and LCD TVs, Camcorders, etc., has increased considerably. The trend has also been facilitated by the easy availability of finance and prevalence of nuclear families are leading to the growth of high-end categories such as LCD/Plasma/LED/3D HD CTVs. An increasing demand for the high-end categories does not mean that the demand for the low-end categories has completely vanished as there is considerable demand for these categories in the rural and semi-urban areas. There is stiff global competition prevailing in the market on durables which has led to fall in prices as well. The consumer is brand-conscious, but not necessarily brand-loyal, and might even pick up a reliable private label if it offers good price and quality values. Consumer durable penetration is one of the lowest in India and the untapped potential is evidently enormous. As Indian consumers continue to attach a high degree of importance to value for money, both manufacturers and traders would be compelled to explore every conceivable method to improve operational efficiencies, in order to achieve substantial and profitable business growth. The Indian consumer durables market has undergone a major transformation since the liberalization process, initiated in 1991. The market size, product penetration, the variety and technology of products sold, have all experienced a quantum leap. Improved product choice and decline in real prices, matched by increased consumer incomes have driven the market growth rate to dizzy heights. The annual market for consumer durables in India (excluding computers and communication products) is currently of the order of Rs. 25,000 crores. The rural market is growing at a much faster rate than its urban counterpart, and the former offers encouraging potential for further growth as well. The penetration of durables and home appliances is quite low in India, compared to several other developing countries. The demand for durables has grown by leaps \& bounds, because of the transformation of the middle class, in terms of numbers, higher disposable income/affordability and changed lifestyle and liking for new technology products like 3D/LED/LCD TVs and frost-free/Side by Side refrigerators of higher capacity, split AC Units, microwave ovens and induction cookers, LPG Hobs/Chimneys etc. In view of the wide variety of choices available, consumers enjoy a higher bargaining power. Further, the demand for many consumer durables is cyclical

*Corresponding author: Anilkumar N, Research Scholar and Chief Manager Department of Commerce and Business Management, Karpagam University, Coimbatore, India, Tel: 09447986364; E-mail: aniln@factltd.com

Received September 03, 2014; Accepted November 25, 2014; Published December 05, 2014

Citation: Anilkumar N, Joseph J (2014) A Contrasting Evaluation of Consume Purchase Attitude-behavior of Urban-Rural Working Women Consumers towards White-Brown Durables, a Study with Specific Relevance to Kochi, Kerala. Int J Econ Manag Sci 3: 207. doi: 10.4172/2162-6359.1000207

Copyright: (c) 2014 Anilkumar N, et al. This is an open-access article distributed under the terms of the Creative Commons Attribution License, which permits unrestricted use, distribution, and reproduction in any medium, provided the original author and source are credited. 
and seasonal. Prompt and efficient service systems based on call centers and the internet, have become the norm. Product Development and Innovation using cutting edge technology is the call of the day for leading brands. Samsung introduced refrigerators with smaller deep freezers and larger crispers for vegetarians; Electrolux brought out refrigerators with pedal operated door opener, changeable panel door and with long legs (to obviate the need for a stand), Side by side configuration by major brands, integral USB and MP3 with FM radio by Godrej, remote control, and a host of other features. Indians do exhibit a reasonable degree of brand loyalty with regard to Fast Moving Consumer Goods (FMCGs). People often tend to buy the same brand of toilet soap, toothpaste or detergent, month after month, for several years. But this is not the case with consumer durables [1-3]. When a television or a refrigerator is to be replaced, it is quite likely that it would be replaced with one of a different brand, even if there was nothing unsatisfactory about the earlier purchase. Further, in the same household, television, CD/DVD player, refrigerator, microwave oven and other gadgets may be of different makes. Indian consumers continue to attach a high degree of importance to value for money, which is reflected in Kerala The rural market demands are catered to mainly by dealers in the nearby urban centers. There are very few outlets that are actually located in the rural areas. Low priced and refurbished second-hand items obtained from exchange offers in urban areas are sold in the rural markets at low prices. A combined "Dealer push and advertising pull" is evidenced in durables. Creativity in advertising has become quite important as a differentiator, as there is nothing much to differentiate between two competing products on the basis of either technology, quality or performance. Advertisements that target lifestyle and emotional appeal-creating healthy food, healthy air, detergent-free clothes, causing neighbor's envy, and such other aspects, have become important elements of advertising content. Festivals and new year promotions have become inescapable marketing tools. This also gels well with the traditional Indian mindset of considering festivals as auspicious occasions for buying valuables. Most manufacturers are compelled to resort to discounts and promotions to protect their domains during the peak buying periods, and to poach customers from competing brands. Attractive schemes can cause a considerable brand shift within the same league. As consumer durables do not necessarily precipitate immediate and urgent requirements, many households tend to postpone purchase decisions so as to take best advantage of the festival discounts. Most of the retailers are individual-owned single outlet dealerships handling multiple brands. Exclusive showrooms are comparatively few in number. There are exclusive outlets of several consumer durable companies such as Sony World, LG Shoppe, ONIDA Arcade, Samsung Plaza, Videocon Mall, Philips and Godrej House as also in Malls creeping up. Less than 10\% of consumer durables are sold through organized retail outlets like exclusive company showrooms and multi-brand outlets of durableschains. There are around 26 major shops in Kochi metro and more than 138 shops mostly in the semi urban satellite towns and fewer within the rural panchayat areas of Ernakulam district. Service centers are also outsourced by the OEM and located within the city accessed through call centers and locally. Of late in the urban areas, consumer exploitation through the crowd-pulling power of shopping malls to push the sales of consumer durables [4]. Oberon, Lulu, Gold Souke Grande and Spencer etc in Kochi. Major dealers like Green home appliances, Bismi, Majestic, White planet, Kuruvithadam agencies, Pittapallil, Nandilath G mart, QRS, Fridge house, Alappat super shoppe in the Kochi city are major players in durable selling. Malls are however not very attractive for retailing consumer durables due to the high real estate cost. Nonetheless, the shopping malls have become a favourite shopping center for Kochi nites. Growth of modern retail formats has necessitated wider product portfolio in order to ensure higher bargaining power and shelf presence. Wider product range is also useful for strengthening brand image among consumers and to even out seasonality in sales, thereby ensuring better use of resources and continuous cash flows [5]. Towards this end, Godrej has begun making color TVs and DVD players. Mirc Electronics has introduced ONIDA washing machines and air conditioners. More imports and less Domestic Production is now evidenced in India. At present, about $60 \%$ of the domestic demand for durables is met by local manufacturing, while the rest is achieved through imports. Most microwave ovens, DVD players and split ACs sold in India are imported. As and when the Indian rupee is devalued with US dollar, the imports are costlier leading to higher prices for durables [6]. The marketing of consumer durables in India is heading for a major transformation in the immediate future, in terms of product range, sources of supply, advertising and promotional measures, manufacturer-trader relationships, innovations in distribution methodology, new retailing formats, etc. with higher Value to price ratio.

For every consumer in urban areas, three in rural areas exist, a ratio of 1:3 in size. Though the proportion of rural population to total population is showing a slight decrease over the years, in absolute numbers the rural population is increasing at a higher rate than the urban population. Industry giants are waking up to the potential of India's rural market of nearly 625 million consumers. The main problems faced by rural consumers are over claying, spurious goods and lack of after-sales services. The rural sector is increasingly playing a major role in the country's market consumption pattern and accounts for nearly two-third of its private consumption [7]. Nearly $90 \%$ of the villages have shops where well-known national brands are available. Rural markets are growing at five times the rate at which the urban markets are growing. The Indian rural market is much larger when compared to the urban market in terms of population and number of households. In rural areas the economy revolves around agriculture as the main production sector and rural industries as the subsidiary production sector [8]. The market for rural industries products is unorganized and dominated by the middlemen to a large extent. The main factors contributing to the growth of the rural market in India aregrowth of rural income, growing population and rural development programs sponsored by the Government. Apart from these major factors, improved infrastructural facilities, increase in productivity in agriculture, expansion of TV / satellite network, WWW and Land/ Mobile communications, improved transportation vehicles and road/ rail/water navigation facilities, expansion of rural retail network, credit availability, banks/ATM centers/insurance firms, courier services and changing lifestyle are certain other factors which are responsible for the growth of rural markets in Kerala [9]. The villages in kerala specifically in and around Ernakulam (the commercial hub of kerala) are closely adapting the patterns of the city in standard of living, habitat and spending on durables. The villages in Ernakulam district(Kerala in general)are densely populated unlike other parts of India but with traditional lifestyle in dress/food/daily routines on personal cleanliness and transparency/simplicity in direct sincere contacts with others persona inside the village/outside.

\section{Rural Consumer}

From the literature review, it is learnt that the rural consumer is less literate/communicative, conservative/utility oriented, loves traditional values/serious and adheres to sociocultural customs/practices, simple, brand loyal. Emotional, adopts savings oriented lifestyle, the family 
decision making rests with the eldest male member only [10-12]. They are cautious, family loving, slow decision makers ,lesser use of cosmetics, conservative, limited learning capacity/evaluation capability, brand awareness lacking, group response dependent, slower and little urgency in lifestyle, enough time available to hold on to traditional family values, hesitant, difficult to access due to psychological barrier/ apprehensions against outsiders and adopts planned buying patterns like complex buying with higher involvement as perceived risk is higher and less innovative to try proven products only [13]. They are price sensitive, looks for reliable products, heterogeneous in grouping on income and wealth, loves finance/credit facility in purchases, not brand loyal, limited infrastructure facilities with large geographic area, warmer social connectivity and cultural ethnicity, lesser information dissemination on products and festival oriented purchases-seasonal. Loves TV and Ads and no classified secondary data available. Interview method most suited to elicit information. Lesser variety and availability of brands at fewer retail outlets in villages. Delayed after sales service as wide spread market in rural district-poor infrastructure. The rural consumers show certain distinctive characteristics which make them different from urban consumers [14]. The following major characteristics define the rural consumers.: Low Education Profilenormally illiterate and at the best has much lesser education than urban counterpart; Low Income Levels- has a much lower income than urban counterpart. A large part of this income goes to provide the basic necessities, leaving small incomes to be spent on other consumer goods. This makes the rural consumer much more pricesensitive than the urban consumer. The rural demand is for low priced products; Occupations- principal occupations in rural area are owners/ workers in Paddy/Vegetable / cash crops farming, trading, crafts and other odd jobs like plumbing ,masonry, farm casual labor, fish/poultry /animal husbandry, trading/retailing, bank and health centers, primary schools and electric works; Reference Groups like the primary health workers, doctors, teachers and the panchayat members, village traders or the grocery shop owners influence in the rural customer's decisionmaking; Media Habits -though all types of media are used in rural areas, in view of the low level of literacy audio-visual media such as FM radios [15], TV channels ,WWW/Broadband-Satellite DTH connections and films assume major importance, with the increased rate of literacy, newspapers/magazines are also of importance in the rural context. In Kerala or Ernakulam district, the gap between the rural and urban is narrowing down, due to success in literacy mission with highest literacy rate in India and highest importance for education, mobile communication revolution, better nutrition-healthcare facilities and lower mortality rates(higher life index), encouraging self-employment schemes, various GOI social welfare schemes implemented through local bodies for the old, women and youth, setting up of IT/Technology parks and small scale export oriented industrial centers, tourist centers in potential rustic areas, better road-rail connectivity/logistics [16], electrification, drinking water and drainage-waste disposal/recycling schemes under overseas soft loans and widespread ownership of 2 wheeler/ 3 wheeler and personal cars revolution, highest legal and human rights awareness, wider media coverage and migration to white collar jobs in Indian cities and abroad. Middle class consumers are more in number in villages and most of them are commuting to the city/towns though living in the villages. Interview required to elicit response from the villagers [17]. The spending on durables during Onam/ Bakrid/Vishu/X mas/Diwali by traditional Keralites is well known.

Most of the WW living in HHs in rural areas attend job in offices located outside the village in towns/city by daily commuting by rail/ road/ public or shared transport /own vehicle. Many have independent economic status at home but short of time amidst the balancing roles at home and job fronts with gender equality in career growth. The employment rate of women in HHs of Kerala have been increasing at a very fast pace, with the influx of IT/Software education and great demand for employment for educated qualified women in IT sector, banking, insurance and medical/schools/colleges in the Government and private /self-financing sectors. The job market in private has been burgeoning in the past decade in Kochi

\section{Urban Consumer}

The urban segment of consumers dwell in the city/town habitat with lower family size, higher education level, internet savvy, communication tools intensive, innovative, modern -western styled, experienced, individualistic with time pressure, willingness to try/accept new/fun and frolic based, easier access and receptivity, enjoyment lifestyle oriented, strong brand favor, eco-friendly, supports joint decisions, follows celebrity endorsement/entertainment oriented, value sensitive, more product attribute sensitive than brand loyalty, credit facility and technology type most important, brand switcher, greater role allotted for women, higher availability of products and affordability/income, risk taking and higher awareness, cognitive, loves luxury/brown goods more, health conscious, consumption friendly, global in outlook, innovative, liking for online shopping with Flipcart, Amazon, Mynthra and E banking and bills payments, E commerce/ Online purchases, organized and premium brands/products of high tech type. Adopts impulsive/emergency buying often as per need due to better availability in large number of retail outlets, homogeneous group-income based like Middle Class and confined to a limited area in the developed area like city with better infrastructure facilities for commuting and transactions. Structured questionnaire in survey easily answered. Higher propensity to spending as well as higher purchasing power leading to purchase of luxuries like Gold/silver/Diamonds, Silk / branded readymade apparels, expensive watches/footwear/cars/Villas and Suites specifically in Kochi city. The Gulf NRI money-remittance and increasing family run business houses have been contributors to higher purchasing power and the modern cosmopolitan lifestyle adaptation fashion/prestige and status consciousness-competition by the middle class consumers in Kochi. Materialistic comforts and possessions are now reckoned with admiration causing conspicuous and expensive purchases, though the spending for calorie rich non veg food, education and healthcare are the highest in India. Brown goods are in great demand to seek leisure and recreation. There exist high competition among durable brands, deeper penetration and larger brand loyalty in urbanites. The Assets ownership is much higher for urbanites in durables with mostly brown goods and the use of cosmetics very high.

\section{Middleclass Working Women}

The middleclass working women are educated with high legal literacy, gatekeepers and deciders for major purchases. They are cautious but not averse to new products/ideas/luxury/fashion, in that both quality and cost, value for money govern their purchase decisions. Though price sensitive they rely on WOM communication than Advertisement messages in mass media. They spend more for keeping up status and earn respect from others. The rural-urban divide in durables among MC working women is likely to be negligible, which is a goal in this study. Labor force participation of women and paid employment raises the quality of Life not only at the level of the $\mathrm{HH}$ but also for the society at large. Also Kerala is noted for the remarkably high level 
of social welfare and development within south Asian nations health, education and demographic changes and exhibiting radical shift from the traditional Malayalam customs to modern accultured lifestyle of today. They are future oriented with long term goals and more rational ,majority loves urban life with wider choice in solutions to problems, willingness to take risk with highest involvement, savings oriented, loves recreation/travel/hobbies, outer values driven lifestyle based, professional outlook/Achievements driven, values SRG recognition, engages in conspicuous purchases, education and healthcare are high priority self-confident, involves in social programmers and Status conscious seeking social recognition.

\section{Consumer Choice Criteria for Durables}

The taste of consumer is wide ranging and constantly changing. The correct prediction for consumer durable decisions is difficult while the final purchasing decision of the consumer will differ between decision styles and profiles cannot be directly applied to unique purchase situations wherein the level of involvement of the consumer varies. The Personal factors and situational factors make it difficult to predict Consumer decisions beforehand. The personal factors embrace self-image, Lifestyle and sub-cultural aspects shaping the consumer's beliefs and influencing the purchase attitude. Lifestyle is a psychographic variable of values/tastes which manifest as needs/ preferences and specific purchase behavior. The purchase decision made by the consumer can alter/reinforce their lifestyle. Consumers are free to select products that reinforce their definitions of selfimage and their perceived unique lifestyle in the family/society so as to acquire satisfaction in life and express self-concept. Consumers perceive products as an extension of their personality and hence deliberate the product choice that matches some aspect of the selfimage and communicates a desired image. Consumers attach symbolic meaning to durables in order to define themselves through the attitude functions served. The consumer purchase decision is individualistic; the complexity of the decision depends on the degree of information search, the evaluation of alternatives and choice of products. Personal factors, Situational/marketing/environmental factors and post purchase behavior factors simultaneously interact each other to influence the consumer's purchase decision. Consumer purchases durables in response to a recognized specific need. The purchasing behavior is also diverse in style as per the taste/values of the consumer. $\mathrm{Du}$ Preez illustrated that the complexity of the purchase decision depends on the extent of consumer's information search, which as per Du Plessis and Rousseau depends on the consumer's personality rather than the consumer durable product.

\section{Product Attributes-benefits for Durables}

The criteria which a buyer employs during information search and when selecting a consumer durable have generally the following attributes: Product Technology/Quality: Consumer durables are technology driven. The latest models, innovative features and improved performance levels are a definite attraction for the customer. The consumer's choice today depends on the premium quality and technology provided; Style: As most of the consumer durables are now a part of kitchen or drawing room furniture, reflecting tastes and lifestyles, the external features play an important role in purchases. The style of durables is turning into a big purchase influencer; Brand Image: The perception of the consumer about the brand name is becoming critical on account of the huge investment made in buying a consumer durable and its durable nature. With the fast approaching disparity in both technology and prices, brand image is becoming a key purchase influencer; Price: The market has been very price-sensitive in the past. The intensity has increased as one moved down from the premium segment to the mass consumption range. However, of late consumers have started showing an inclination to buy medium price range products as opposed to low priced products. The consumer is becoming more sophisticated and beginning to recognize the value of premium quality; After Sales Service: As more and more brands of consumer durables are becoming more or less similar in terms of technology and price, the after-sales service has assumed a major influence in buying decisions. This factor is assuming a key role in the minds of the consumers, as the consumer durables are becoming more and more complex. Moreover, the latest technology requires professional help for full usage. Hence, the consumers are likely to depend more on service support. Some consumers buy durables that match /reflect their aesthetic taste and lifestyle/Personality. Also various personal intentions underlie the purchase decision making of the consumer like satisfaction, security, self-concept, product attributes, etc. It is presumed that the consumer adopts extensive problem solving behavior with more time and search, evaluation process accorded for durables in consonance with the financial value, personal/social importance and visibility accorded to the product/purchase act. The consumer profile like the income/disposable income or affordability matching the benefits and willingness to pay higher price(not price sensitive), brand availability with differentiation/variety, lifestyle adopted, higher importance accorded to product attributes, benefits driven approach and the dynamic marketing mix aspects influence the purchase of consumer durables. There are two classes of Durables-the white goods and the brown goods. While the white goods are relatively higher priced, heavier, slower in replacement purchases, practical utility oriented, Warrantee-Insurance with after sales service intensive and energy saving designs sought after by the consumer; the brown goods are mostly electronic goods which are lighter in weight, relatively replaced at a faster pace than white goods, specific high technology skills-knowledge required to operate/maintain and are entertainment oriented employing the latest innovative technology of miniature type with wireless communication facilities. Traditionally, the White goods are functional utilities while the brown goods are of entertainment value at the $\mathrm{HH}$, though both extend durability and similar product attributes on several accounts. Durables are slow moving merchandises from retail outlets but investment intensive ,there exist long time gap between successive purchases by a consumer for a product type, hard goods with higher returns for the retailor though volume/number of off take/sales lower involving higher investment for the consumer demanding higher involvement due to higher price/risk perception involved.

\section{Scope/Objectives of the Study}

The major objective of this study is to analyze the difference between the purchase attitude-consumer behavior of urban and rural MC Working Women consumers in terms of their PEOU for Durables product attributes in the choice criteria, like salient attributes technology, style, brand image, price and after-sales services, etc.; Key benefits/PU derived from Durables for domestic consumption; Personal factors-demographic profile like age/FLCS-size, Education level. Occupation, disposable income of family, lifestyle/self-image, beliefs/perception, Subcultural traits etc., SRG/SN -Normative social factors with importance to other's opinion and marketing Mix factorProduct/price/promotion/place/possession on the purchase behavior. Attitude object chosen is durables.

\section{Formulation of Null Hypothesis}


Citation: Anilkumar N, Joseph J (2014) A Contrasting Evaluation of Consumer Purchase Attitude-behavior of Urban-Rural Working Women Consumers towards White-Brown Durables, a Study with Specific Relevance to Kochi, Kerala. Int J Econ Manag Sci 3: 207. doi: $10.4172 / 2162-6359.1000207$

Page 5 of 8

(1)H01: There is no significant difference between the urban and rural consumers as far as the weight age of the salient attributes on their purchase preference for durables is concerned;

(2)H02: There is no significant difference between the urban and rural consumers as far as the impact of key benefits on their purchase preference for durables is concerned;

(3)H03: There is no significant difference between the urban and rural consumers as far as their personal profile and purchase preference for durables is concerned;

(4)H04: There is no significant difference between the urban and rural consumers as far as their social personality and purchase preference for durables is concerned;

(5)H05: There is no significant difference between the urban and rural consumers as far as the market mix influence on their purchase preference for durables is concerned.

\section{Research methodology}

The research design has been adopted as an empirical study based on primary data to evaluate the consumer attitude-behavior with the working women in focus. The data has been collected through a tool of combination of direct personal interviews and questionnaires. To conduct these study 260 rural consumers $(50.12 \%$ responded) and an equal 260 urban consumers responses (71.65\% responded) collected from Ernakulum in 2014. For urban consumers, the 10 Pockets of Kochi metro obtained (with 26 numbers of families in each pocket) and for rural consumers, 20 numbers of Panchayats in remote underdeveloped interior villages selected at random (with 13 numbers of families in each village) in Ernakulum District have been chosen. Judgment sampling has been adopted as the sampling method for the selection of urban and rural respondent families, due to time/ cost/access constraints. The questionnaire was used among urban respondents while both questionnaire and interview schedule adopted with rural working women of middle class HHs, amidst the busy life of respondents.

\section{Data analysis}

The demographic profile of the urban and rural consumers is listed vide Table 1 in below. Obviously the education profile, occupational status and income of rural consumers are inferior to that of urban counter parts.

The specific income distribution of households is listed vide Table 2 below. In the rural HHs the majority are well off (60.1\%) while in the rural HHs, the majority are climbers $(53.52 \%)$ in the middle class segment.

The Durable products are categorized as White goods for kitchen and cleaning utility services and brown goods for entertainment purpose in two separate classes for analysis. The decision rule applied by the consumers in the purchase of each class is elaborated vide Table 3 below. In both classes the compensatory rule is most widely applied by consumers.

Each $\mathrm{HH}$ in the Urban and rural mile has locational differences and environmental impact in habitation. Accordingly the assets inventory of each $\mathrm{HH}$ in Urban and rural are categorized and summarized in Table 4 below. Maximum Ownership of Mobile phones, CTV are followed by refrigerators and luxury cars/premium two wheelers in the urban households; while in the rural HHs, mobile phones, CTV are followed by refrigerator, real estate ownerships are prominent.

\begin{tabular}{|c|c|c|c|c|}
\hline S.No & Charts & Variations & $\begin{array}{l}\text { Urban } \\
(\%)\end{array}$ & $\begin{array}{c}\text { Rural } \\
(\%)\end{array}$ \\
\hline \multirow{4}{*}{1} & \multirow{4}{*}{ Age } & $20-29$ years & 8.2 & 9.4 \\
\hline & & 30-39years & 41.93 & 43.28 \\
\hline & & 40-49years & 36.74 & 28.64 \\
\hline & & 50-59years & 13.13 & 18.68 \\
\hline \multirow{5}{*}{2} & \multirow{5}{*}{ FLC Stage } & Full Nest I(child<8 yrs) & 20.49 & 18.68 \\
\hline & & Full Nest II(child $>8$ and $<16 y r s$ ) & 34.87 & 29.17 \\
\hline & & Full Nest III(child >16yrs) & 22.41 & 19.84 \\
\hline & & Empty Nest(Young and older) & 12.84 & 17.61 \\
\hline & & Others & 9.39 & 14.7 \\
\hline \multirow{3}{*}{3} & \multirow{3}{*}{$\begin{array}{l}\text { Family } \\
\text { Type-size }\end{array}$} & Nuclear- 1 to 5 members & 67.62 & 33.12 \\
\hline & & Joint -5 to 9 members & 29.32 & 48.13 \\
\hline & & Joint- 9 to 15 members & 3.06 & 18.75 \\
\hline \multirow{4}{*}{4} & \multirow{4}{*}{ Education } & SSLC & 2.94 & 9.74 \\
\hline & & Graduate & 14.59 & 32.91 \\
\hline & & Post Graduate & 41.62 & 36.43 \\
\hline & & Professional and higher & 40.85 & 20.92 \\
\hline \multirow{4}{*}{5} & \multirow{4}{*}{ Profession } & Government employee/PSU/University & 37.83 & 14.58 \\
\hline & & $\begin{array}{l}\text { Private firms employment/Schools/ } \\
\text { Colleges }\end{array}$ & 24.91 & 42.64 \\
\hline & & Business/Law/Medical/Accountancy & 27.17 & 22.31 \\
\hline & & Others-self-employed,. & 10.09 & 20.47 \\
\hline \multirow{4}{*}{6} & \multirow{4}{*}{$\begin{array}{l}\text { Disposable } \\
\text { Family } \\
\text { Income per } \\
\text { month }\end{array}$} & $>=1$ Lakh INR & 9.12 & 7.96 \\
\hline & & $50,000 /-$ to 1 Lakh INR & 56.49 & 10.73 \\
\hline & & $25,000 /-$ to $50,000 /-$ INR & 26.71 & 59.49 \\
\hline & & $5,000 /-$ to $25,000 /-$ INR & 7.68 & 21.82 \\
\hline \multirow{4}{*}{7} & \multirow{4}{*}{$\begin{array}{l}\text { Dwelling } \\
\text { habitat }\end{array}$} & Self-owned independent house & 22.95 & 63.47 \\
\hline & & Rented independent house & 16.49 & 24.64 \\
\hline & & Self-owned Apartment/Villa & 41.83 & 7.27 \\
\hline & & Rented Apartment/Villa & 18.73 & 4.62 \\
\hline \multirow{4}{*}{8} & \multirow{4}{*}{$\begin{array}{l}\text { Religious } \\
\text { affiliation }\end{array}$} & Hindu & 33.79 & 45.36 \\
\hline & & Christian & 37.61 & 22.71 \\
\hline & & Moslem & 20.77 & 30.63 \\
\hline & & Others & 7.83 & 1.3 \\
\hline
\end{tabular}

Table 1: Demographics of consumers.

\begin{tabular}{|c|c|c|c|c|}
\hline \multirow{2}{*}{$\begin{array}{l}\text { Family Lifestyle/ } \\
\text { Income group in } \\
\text { Sample }\end{array}$} & \multicolumn{2}{|c|}{ Urban households } & \multicolumn{2}{|c|}{ Rural households } \\
\hline & $\begin{array}{c}\text { Annual } \\
\text { Income (Rs.) }\end{array}$ & $\begin{array}{c}\% \text { of } \\
\text { sample }\end{array}$ & $\begin{array}{c}\text { Annual } \\
\text { Income (Rs.) }\end{array}$ & $\%$ of sample \\
\hline V. High Income & \multirow{2}{*}{ 16-20 Lakhs } & \multirow{2}{*}{5.82} & \multirow{2}{*}{ 16-20 Lakhs } & \multirow{2}{*}{3.87} \\
\hline Affluent & & & & \\
\hline $\begin{array}{c}\text { Well Off-Upper Middle } \\
\text { class }\end{array}$ & 16-20 Lakhs & 60.1 & 16-20 Lakhs & 18.01 \\
\hline $\begin{array}{c}\text { Climbers-True Middle } \\
\text { class }\end{array}$ & 8-12 Lakhs & 25.46 & 8-12 Lakhs & 53.52 \\
\hline $\begin{array}{l}\text { Aspirants-Lower } \\
\text { Middle class }\end{array}$ & 4-8 Lakhs & 8.62 & 4-8 Lakhs & 24.6 \\
\hline Total & \multicolumn{2}{|l|}{100} & \multicolumn{2}{|c|}{100} \\
\hline
\end{tabular}

Table 2: Income distribution profile of Consumers.

Washing machines, Air conditioners and home gym equipment's ownership have wide disparity between urban and rural households, for obvious reasons of the rural background in environment/lifestyle.

The most salient product attributes for white goods and brown goods that find place in the consumer mind are listed in Table 5 below. Technology, after sales service and user friendliness are the most salient attributes. Price is not a significant aspect in the purchase like brand in view of the fierce competition in the durables market prevalent in Kochi now. The urban consumer is technology savvy and most innovative. Notable is the high rating accorded by rural consumer for 
Citation: Anilkumar N, Joseph J (2014) A Contrasting Evaluation of Consumer Purchase Attitude-behavior of Urban-Rural Working Women Consumers towards White-Brown Durables, a Study with Specific Relevance to Kochi, Kerala. Int J Econ Manag Sci 3: 207. doi: $10.4172 / 2162-6359.1000207$

Page 6 of 8

after sales service in view of the service center franchisees located in the urban areas. Also the perceptional risk on the user friendliness of the durables is found higher with the rural consumers.

\begin{tabular}{|c|c|c|c|c|}
\hline \multirow{2}{*}{$\begin{array}{l}\text { Decision rule for } \\
\text { evaluation criteria in } \\
\text { purchase of durables- } \\
\text { dominant rule adopted }\end{array}$} & \multicolumn{2}{|c|}{ Urban WW Consumers } & \multicolumn{2}{|c|}{ Rural WW Consumers } \\
\hline & $\begin{array}{l}\text { White } \\
\text { Goods }\end{array}$ & $\begin{array}{l}\text { Brown } \\
\text { Goods }\end{array}$ & $\begin{array}{l}\text { White } \\
\text { Goods }\end{array}$ & $\begin{array}{l}\text { Brown } \\
\text { Goods }\end{array}$ \\
\hline $\begin{array}{l}\text { Conjunctive rule } \\
\text { (non-compensatory) }\end{array}$ & 18.97 & 10.68 & 17.86 & 14.81 \\
\hline $\begin{array}{l}\text { Elimination by aspects } \\
\text { rule (non-compensatory) }\end{array}$ & 31.21 & 26.81 & 28.95 & 20.74 \\
\hline $\begin{array}{l}\text { Disjunctive rule } \\
\text { (non-compensatory) }\end{array}$ & 5.36 & 14.84 & 7.62 & 11.86 \\
\hline $\begin{array}{l}\text { Lexicographic rule } \\
\text { (non-compensatory) }\end{array}$ & 8.24 & 16.26 & 6.73 & 13.44 \\
\hline Compensatory rule & 34.87 & 29.58 & 31.21 & 30.69 \\
\hline Heuristics/Thump rule & 1.35 & 1.83 & 7.63 & 8.46 \\
\hline
\end{tabular}

Table 3: Evaluative criteria adopted by consumers in purchase decision making.

\begin{tabular}{|c|c|c|}
\hline \multirow{2}{*}{ Ownership of durables in $\mathrm{HH}$} & \multirow{2}{*}{$\begin{array}{c}\text { Urban } \\
\% \text { (Sample) }\end{array}$} & \multirow{2}{*}{$\begin{array}{c}\text { Rural } \\
\text { \%(Sample) }\end{array}$} \\
\hline & & \\
\hline Refrigerator & 99.62 & 98.91 \\
\hline Washing machines/Dish washers & 92.84 & 67.35 \\
\hline MWO/OTG & 42.67 & 24.74 \\
\hline Induction cooker/LPG Hobs & 95.24 & 85.38 \\
\hline Vac Vaccum cleaner /Water purifier & 96.38 & 25.62 \\
\hline $\begin{array}{c}\text { LED/LCD/Plasma /FPT Color TV with } \\
\text { STB/DTH }\end{array}$ & 100 & 99.72 \\
\hline Home theatre/DVD Music systems 5.1 & 38.78 & 33.86 \\
\hline Air conditioners/Split AC units & 69.69 & 18.93 \\
\hline Mobile phones(SMART/3G/4G) & 100 & 100 \\
\hline $\begin{array}{l}\text { PC/Laptop with broadband connections/ } \\
\text { Wifi/Tablets }\end{array}$ & 95.42 & 48.93 \\
\hline Home Gym /Health Club Equipments & 56.75 & 8.86 \\
\hline Two wheelers and Cars(Luxury) & 99.87 & 76.65 \\
\hline House/Apartment/Plots/real estate & 63.54 & 94.21 \\
\hline
\end{tabular}

Table 4: Ownership Inventory of Households
The behavioral styles adopted by both the rural and urban consumers are different for the white and brown goods, as delineated by their response collated below vide Table 6 . The basic needs like safety and affiliation are most dominant herein among the consumers. Aesthetic/hedonic influence for brown goods is significant among urban consumers, while ethical aspect is predominant among rural consumers. Peer pressure and social comparison are also significant among both urban and rural consumers. Affiliation and Esteem needs are more pronounced for brown goods among both urban and rural consumers covered in the survey.

The various influencing factors on the attitude and behavioral intention leading to actual purchase behavior of both classes of durables for urban consumers are tabulated vide Table 7 below. On the positive front, subjective norms are most prominent on white goods, while the family dynamics is most prominent for brown goods on the consumer $\mathrm{HH}$. On the negative front, among the white and brown goods, past experience is most significant followed by the subcultural aspects, though more pronounced with the brown goods? Also lifestyle, SN and PU are relatively dominant positive aspects for brown goods. Due to heritage/ legacy aspects.SN and PEOU are dominant positive aspects for white goods.

The relative influence of aspects influencing the purchase attitude and behavioral intention leading to actual purchase behavior of both class of durables for rural consumers is tabulated vide Table 8 below. For white and Brown goods, the $\mathrm{SN}$ is most dominant on the positive front while the sub cultural aspect account for the most dominant in the negative front. The relative influence of family dynamics and lifestyle aspects outweigh for brown goods than for white goods. Past purchase reactions and subcultural aspects are most significant among both white and brown goods though more pronounced in brown goods. On the whole, the impact of most factors is seen lesser than for urban consumers except for the past experience and sub cultural factors due to cultural heritage and beliefs overriding in the rural consumers. For the urban consumers the lifestyle aspect is very significant compared to rural consumers.

\begin{tabular}{|c|l|c|c|c|c|}
\hline & Salient Product attributes importance to consumers & \multicolumn{2}{|c|}{ Urban consumer } & \multicolumn{2}{c|}{ Rural consumer } \\
\hline & & White & Brown & White & \multicolumn{1}{|c|}{ Brown } \\
\hline 1 & Technology-quality & 23 & 29 & 15 \\
\hline 2 & Design-Novel style-looks-color/shape-aesthetics-status symbol/uniqueness & 7 & 8 & 2 \\
\hline 3 & Price/Value for money/patronage benefits & 6 & 4 & 9 \\
\hline 4 & Brand Image/credibility & 8 & 9 & 10 \\
\hline 5 & After sales services and Warrantee/spares support & 13 & 15 & 16 \\
\hline 6 & Efficiency-performance-reliable & 11 & 12 & 17 \\
\hline 7 & Energy saving/operating costs & 10 & 4 & 12 \\
\hline 8 & Size/Volume/safety/cleaning convenience/utility comfort & 6 & 5 & 12 \\
\hline 9 & User friendliness/PEOU/Automatic features & 9 & 11 & 10 \\
\hline 10 & Exchange/resale value, durability-usefulness, availability & 7 & 3 & 8 \\
\hline
\end{tabular}

Table 5: Product attributes Importance influencing consumer purchase attitude.

\begin{tabular}{|l|c|c|c|}
\hline & \multicolumn{2}{|c|}{ Urban Consumer } & Rural Consumer \\
\hline Consumer Value in Purchase & White & Brown & Brown \\
\hline Personal benefits/safety & 19 & 25 & 21 \\
\hline Social/family/Love/Peer pressure & 20 & 22 & 21 \\
\hline Economy/Biogenic/Security & 28 & 14 & 30 \\
\hline Achievement/Status-social comparison/Esteem & 16 & 24 & 13 \\
\hline Passive & 9 & 4 & 11 \\
\hline Others/hedonic/Ethical/Aesthetics., & 8 & 11 & 10 \\
\hline
\end{tabular}

Table 6: Consumer behavior styles adopted-buying purpose (in $\%$ of sample size). 
Citation: Anilkumar N, Joseph J (2014) A Contrasting Evaluation of Consumer Purchase Attitude-behavior of Urban-Rural Working Women Consumers towards White-Brown Durables, a Study with Specific Relevance to Kochi, Kerala. Int J Econ Manag Sci 3: 207. doi: $10.4172 / 2162-6359.1000207$

Page 7 of 8

\begin{tabular}{|l|c|c|c|c|c|c|}
\hline \multirow{2}{*}{ Consumer Purchase decision making Enablers through Attitude } & \multicolumn{3}{|c|}{ For White Goods (in \%) } & \multicolumn{3}{c|}{ For Brown goods (in \%) } \\
\cline { 2 - 6 } & + High & Neutral & -Low & + High & Neutral & -Low \\
\hline Perceived ease of use/beliefs on Salient product attributes & 86.63 & 1.15 & 12.22 & 89.25 & 5.49 \\
\hline Perceived usefulness-Belief on product benefits & 81.87 & 9.02 & 9.11 & 90.47 & 5.61 & 3.92 \\
\hline Attitude towards purchase & 74.9 & 9.96 & 15.14 & 85.06 & 9.73 & 5.21 \\
\hline Subjective Norms /Social Influence on personality & 87.93 & 5.75 & 6.32 & 90.45 & 3.57 & 5.98 \\
\hline PBC/Perceived risk/ Importance/Involvement level criteria & 85.63 & 9.39 & 4.98 & 87.56 & 6.91 & 5.53 \\
\hline Behavioral Intention(BI) & 79.78 & 2.68 & 17.54 & 88.36 & 6.82 & 4.82 \\
\hline Personal characteristics-personal/demographic profile Influence & 80.16 & 11.26 & 9.58 & 86.15 & 11.47 & 2.38 \\
\hline Lifestyle and personality/Self Image construct & 82.41 & 8.97 & 8.62 & 89.76 & 9.22 & 1.02 \\
\hline Sub Cultural/Religious beliefs/Social norms/Food habits/Nativity Influence & 37.93 & 28.01 & 34.06 & 35.75 & 25.99 & 38.26 \\
\hline Family dynamics-Spouse-Kids-Parents dispositions Influence & 84.31 & 6.80 & 8.89 & 93.62 & 4.86 & 1.52 \\
\hline Marketing mix/Mass media- Persuasion and Environmental location Influences & 75.37 & 2.29 & 22.34 & 86.49 & 12.25 & 1.26 \\
\hline Past purchase learning /Cognitive dissonance expression/Influence & 23.84 & 27.10 & 49.06 & 23.78 & 23.81 & 52.41 \\
\hline
\end{tabular}

Table 7: Influence of aspects on Urban Consumer for durables (in \% of sample)

\begin{tabular}{|c|c|c|c|c|c|c|}
\hline \multirow[t]{2}{*}{ Consumer Purchase decision making Enablers through Attitude } & \multicolumn{3}{|c|}{ For White Durables (in \%) } & \multicolumn{3}{|c|}{ For Brown Durables (in \%) } \\
\hline & + High & Neutral & -Low & + High & Neutral & -Low \\
\hline Perceived ease of use/beliefs on Salient product attributes & 71.15 & 13.23 & 15.62 & 70.49 & 6.26 & 23.25 \\
\hline Perceived usefulness-Belief on product benefits & 68.12 & 19.85 & 1203 & 59.45 & 21.91 & 18.64 \\
\hline Attitude towards purchase & 65.96 & 7.91 & 26.13 & 19.72 & 55.25 & 25.01 \\
\hline Subjective Norms/Social Influence & 80.75 & 2.73 & 16.52 & 81.45 & 7.68 & 10.87 \\
\hline PBC/Perceived risk/ Importance /Involvement level criteria & 55.39 & 29.68 & 14.93 & 57.56 & 26.83 & 15.61 \\
\hline Behavioral Intention(BI) & 57.77 & 12.59 & 29.64 & 55.34 & 29.78 & 14.88 \\
\hline Personal characteristics-demographic profile influence & 65.10 & 15.59 & 19.31 & 66.15 & 21.18 & 12.67 \\
\hline Lifestyle and personality/Self Image construct & 51.45 & 19.63 & 28.92 & 58.66 & 20.24 & 21.10 \\
\hline Sub Cultural/Religious beliefs/Social norms/Food habits/Nativity Influence & 17.05 & 18.02 & 64.93 & 14.97 & 12.74 & 72.29 \\
\hline Family dynamics Spouse-Kids-Parents dispositions Influence & 68.71 & 4.90 & 26.39 & 71.66 & 6.70 & 21.64 \\
\hline $\begin{array}{l}\text { Marketing mix/Mass media-Persuasion and Environmental location } \\
\text { Influences }\end{array}$ & 54.36 & 2.35 & 43.29 & 61.23 & 17.48 & 21.29 \\
\hline $\begin{array}{l}\text { Past purchase learning /Cognitive dissonance expression/Influence of } \\
\text { Past behavior/Cognitive dissonance }\end{array}$ & 14.10 & 41.83 & 44.07 & 12.72 & 24.46 & 62.82 \\
\hline
\end{tabular}

Table 8: Influence of aspects on Rural Consumer for durables ( in \% of sample).

\begin{tabular}{|c|c|c|c|}
\hline s.no & Influence of mass media/market on HH & Urban (\%) & Rural (\%) \\
\hline 1. & TV & 100 & 98 \\
\hline 2. & Print-Newspaper/Magazines & 65 & 84 \\
\hline 3. & FM radio & 31 & 72 \\
\hline 4. & WWW & 99 & 40 \\
\hline 5. & $\begin{array}{c}\text { Exhibitions/Festival Fairs/Hoardings/Display } \\
\text { boards }\end{array}$ & 48 & 26 \\
\hline 6. & WOM & 27 & 82 \\
\hline
\end{tabular}

Table 9: Media usage influence on purchase of durables.

\begin{tabular}{|c|l|c|c|}
\hline s.no & Important priorities in family spending & Urban (\%) & Rural (\%) \\
\hline 1. & Making money/lnvestments/Savings & 26 & 18 \\
\hline 2. & $\begin{array}{l}\text { Family members-general welfare and assets } \\
\text { buildup for future }\end{array}$ & 17 & 23 \\
\hline 3. & Healthcare of members & 9 & 10 \\
\hline 4. & Education & 14 & 15 \\
\hline 5. & Investment on Children & 9 & 13 \\
\hline 6. & Parental care/medical aspects & 5 & 12 \\
\hline 7. & Profession/ career betterment & 6 & 3 \\
\hline 8. & Entertainment/relaxation/fashion & 8 & 2 \\
\hline 9. & $\begin{array}{l}\text { Socialization-association in groups/Club } \\
\text { memberships/Community services }\end{array}$ & 6 & 4 \\
\hline & Total & 100 & 100 \\
\hline
\end{tabular}

Table 10: Priority in family on spending.
The market mix uses promotion through advertisement persuasion messages aimed at changing the attitude functions of the consumer through product positioning and consumer target segmenting methods. The relative influence of the mass media in promoting higher awareness and brand consciousness for durable goods among the both class of consumers is enlisted below in Table 9. The influence of print, WOM and radio is higher among rural consumer HHs while Internet and Exhibitions are more prominent among urban consumers. CTV is equally effective and most prominent among both classes of consumers.

The urban and rural $\mathrm{HH}$ spending priority is important in the consumer behavior study. The priorities accorded in the Family for various heads is elaborated vide Table 10 below. The most priority accorded among urban consumers is money making and asset building/general welfare of family. In contrast, for the rural consumers, general welfare of family members/assets buildup is most prominent followed by savings and education. Parental care and investment on children are more pronounced among rural consumers than urban consumers. However, relatively higher importance has been accorded for professional growth, entertainment and socialization among the urban consumers.

Testing of Hypothesis: The listed null hypotheses are tested vide Correlation analysis as per Table 11 below:

H01: There is no significant relation between the urban and rural consumers as far as the weight age of the salient attributes on their 
Citation: Anilkumar N, Joseph J (2014) A Contrasting Evaluation of Consumer Purchase Attitude-behavior of Urban-Rural Working Women Consumers towards White-Brown Durables, a Study with Specific Relevance to Kochi, Kerala. Int J Econ Manag Sci 3: 207. doi: $10.4172 / 2162-6359.1000207$

Page 8 of 8

\begin{tabular}{|c|c|c|c|c|c|c|c|c|}
\hline \multirow[t]{3}{*}{ Correlation } & \multicolumn{4}{|c|}{ Urban Consumers $(\mathrm{N}=\mathbf{2 6 0})$} & \multicolumn{4}{|c|}{ Rural Consumers(N=260) } \\
\hline & \multicolumn{2}{|c|}{ White Goods } & \multicolumn{2}{|c|}{ Brown Goods } & \multicolumn{2}{|c|}{ White goods } & \multicolumn{2}{|c|}{ Brown goods } \\
\hline & $\begin{array}{l}\text { Cor.Coefft } \\
\text { R Value }\end{array}$ & Sig. & $\begin{array}{l}\text { Corcoefft } \\
\text { R Value }\end{array}$ & Sig. & $\begin{array}{c}\text { Corcoefft } \\
\text { R Value }\end{array}$ & Sig. & $\begin{array}{l}\text { Corcoefft } \\
\text { R Value }\end{array}$ & Sig. \\
\hline PEOU/Salient attributes of durable products & 0.66 & 0.01 & 0.68 & 0.01 & 0.59 & .01 & 0.57 & 0.01 \\
\hline PU/Key benefits of durable products & 0.63 & 0.01 & 0.74 & 0.01 & 0.56 & .01 & 0.51 & 0.01 \\
\hline Personal profile & 0.62 & 0.01 & 0.73 & 0.01 & 0.55 & 0.01 & 0.56 & 0.01 \\
\hline Social profile & 0.71 & 0.01 & 0.73 & 0.01 & 0.61 & 0.01 & 0.63 & 0.01 \\
\hline Current Market mix & 0.59 & 0.01 & 0.72 & 0.01 & 0.38 & 0.05 & 0.49 & 0.01 \\
\hline
\end{tabular}

Table 11: Relationship between consumer preference/purchase attitude and independent constructs.

purchase preference for durables is concerned. The null hypothesis is rejected as $r$ value is positive and statistically significant at 0.01 for both white goods and brown goods.

H02: There is no significant relation between the urban and rural consumers as far as the impact of key benefits on their purchase preference for durables is concerned. The null hypothesis is rejected as $r$ value is positive and statistically significant at 0.01 for both white goods and brown goods.

H03: There is no significant relation between the urban and rural consumers as far as their personal profile and purchase preference for durables is concerned. The null hypothesis is rejected as $r$ value is positive and statistically significant at 0.01 for both white goods and brown goods.

H04: There is no significant relation between the urban and rural consumers as far as their social personality and purchase preference for durables is concerned. The null hypothesis is rejected as $r$ value is positive and statistically significant at 0.01 for both white goods and brown goods.

H05: There is no significant relation between the urban and rural consumers as far as the market mix influence on their purchase preference for durables is concerned. The null hypothesis is rejected as $r$ value is positive and statistically significant at $0.01 / 0.05$ for both white goods and brown goods vide above. It is concluded from above that there is a significant positive association between the nature of the consumer (i.e., urban or rural) and their preference/attitude while purchasing a consumer durables (both white and brown goods). Durables are today a necessity than luxury in view of modern acculturation in lifestyle.

\section{Conclusion}

Now premium brands are gaining wide acceptance in the rural markets. Urban and rural markets significantly differ from each other in considering general and product-specific factors while making their purchase decisions for durables. Urban and rural consumer behavior are related as also different on various fronts as discussed earlier while making a purchase decision for buying a consumer durable (White or Brown). Marketers of consumer durables have to evolve appropriate strategies on product positioning and market segmentation catering to both the urban and rural consumers for the white and brown goods in the wide spectrum of durable products for domestic consumption aimed at MC.

\section{References}

1. Belch MA, Willis LA (2002) Family decision at the turn of the century: Has the changing structure of Households impacted the family decision making process, Journal of Consumer Behaviour 2: 111-114.

2. Bijapurkar R, Ravi Murthy (1999) Rural markets for consumer durables, The Economic Times,16Aug.

3. Business world Marketing White book (2011), Kolkata.
4. Krishnamacharyulu CSG, Lalitha Ramachandran (2008) Rural marketing-Text and Cases, Pearson Education Asia.

5. Davis HL (1976) Decision making within the household, Journal of Consumer Research: pp241-60.

6. Etzel M, Walker BJ, Stanton W, Pandit A (2008) Marketing concepts and cases 13thed, Tata Mcgrawhill, New Delhi.

7. FICCl's Consumer Durables Survey, October 2011

8. Gopalaswamy TP (1997) Rural Marketing, Wheeler Publishing House, New Delhi.

9. Hakansson, Hakan, Alexandra W (2005) Developing a new understanding of markets: Reinterpreting the $4 p$ 's. Journal of Business and Industrial marketing 20: 10-117.

10. Kotler P, Ang SH, Leong SM, Tan CT (2003) Marketing management: An Asian perspective, Singapore, Pearson Education Asia.

11. Nagaraja B (2004) Consumer behavior in rural areas: A micro level study on buying behavior of rural consumers in Kavalimandal, Indian Journal of Marketing 34: 30-36.

12. Philip Kotler (2005) Marketing Management, Prentice Hall of India, New Delhi.

13. Qualls WJ (1984) Sex roles, Husaband-wife influence and Family decision behavior, Advances in Consumer Research 11: 270-75

14. Rahman SM, Saxena A, Dwivedi H (1997) Rural Marketing: Thrust and Challenges, National Publishing House, New Delhi.

15. ORG-MARG Rural Consumers (2010) Survey reports.

16. Ratra Amiteswar (2006) Working and Non-working Women, Mittal Publication, New Delhi.

17. Schiffman Kanuk (2000) Consumer Behavior, Prentice Hall of India, New Delhi. 